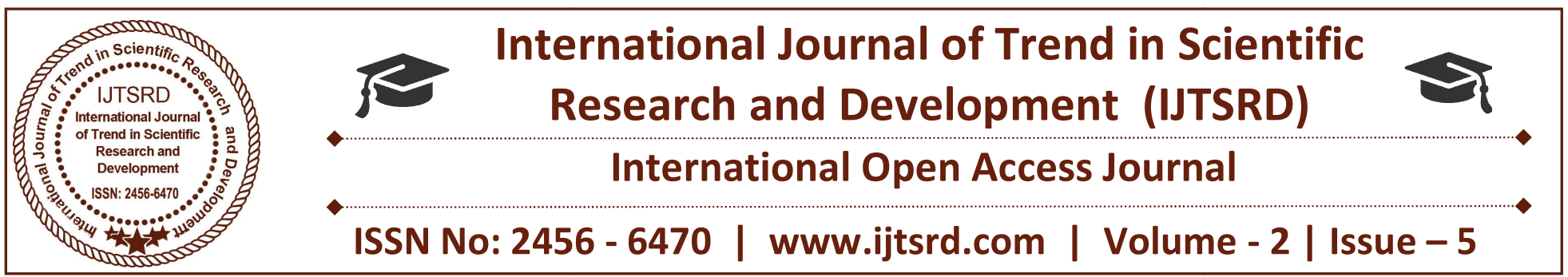

\title{
Unconscionable Contract
}

\author{
Bhanu Prakash Singh Markam \\ B.B.A., LL.B (Hons), Indore Institute of Law \\ Indore, Madhya Pradesh, India
}

\section{Unconscionable}

Courts use the term "unconscionable" to describe conduct that is either unjust or one-sided to benefit one party more than the other. In contract law, an unconscionable contract is one that no reasonable person would enter into without some very compelling reason. Those who do end up entering into unconscionable contracts tend to be poorly educated, living in poverty, or have been unable to find a fairer agreement elsewhere.

\section{Definition of Unconscionable}

\section{Noun}

Conduct that is unfair or one-sided so as to provide more of a benefit to one party over another.

\section{Origin}

$1555-1565$

\section{What is Unconscionability}

Unconscionability is a term in contract law that is used to describe the terms of a contract that are so severely unfair or one-sided that no reasonable person would enter into such a contract. Because of how unreasonable an unconscionable contract is, the contract is considered by law to be unenforceable. This is because it would not be fair for the person who drafted the contract to benefit from his deliberate deception. It would also be equally unfair not to let the other party out of a contract that was drafted for the purpose of deceiving him.

For example, unconscionable language consists of terms or phrases that the average person would not understand. This lack of understanding would then be glossed over by the perpetrator in his attempt to have the other party sign a contract that he would not have agreed to, had he more fully understood what he was signing.

A contract of sale to purchase a home wherein the real estate agent inserted hidden fees or other shady terms that are written in "legalese" would be an example of unconscionable conduct. Without seeking the assistance of an attorney, the average person may not understand what he is agreeing to, but may agree to it anyway due to a lack of education on the subject, or the belief that he will not find a better deal elsewhere.

\section{Unconscionable Conduct}

Unconscionable conduct is typically found in cases that involve fraud or deception. This is because one party deliberately misrepresents the facts to deprive someone else of something valuable, such as money or property. In effect, the person exhibiting the unconscionable conduct is stealing from, or otherwise taking advantage of, the other person. Unconscionable conduct can be punished as either a criminal fraud, or with a civil action. A contract is more likely to be found to be unconscionable if it contains both unfair bargaining practices and one-sided terms.

\section{Unconscionable Contract}

A contract is considered unconscionable when the person drafting the contract was acting with unconscionable conduct at the time the contract was being drafted. The fact that events may transpire later on that provide one party with more of an extreme benefit than the other is irrelevant, and do not make for an unconscionable contract. Unconscionability must exist at the time the contract is drafted in order 
for the contract to be declared void, and for the drafter to be punished accordingly.

There are no set guidelines insofar as determining whether a contract is unconscionable. It is left up to the discretion of the judge or jury that is presiding over the case. An unconscionable contract is one that would be a mockery of the judicial system if the court were to let it stand. Damages are not typically awarded upon a court's finding of a contract to be unconscionable. However, there are other remedies available at law that a court can pursue.

For instance, the court may refuse to enforce an unconscionable contract, arguing that the party who was unfairly treated was misled, lacked the information necessary to make such a decision, or signed under duress. Alternatively, the court may refuse to enforce only the clause that makes the contract unconscionable and uphold the rest.

\section{Procedural Unconscionability}

Procedural unconscionability is a term used to describe the very unfairness that makes a contract an unconscionable one. Procedural unconscionability refers to the disadvantage suffered by the misinformed party upon consenting, against what would have been his better judgment, to extremely unfair terms. There are two main factors that make up procedural unconscionability: oppression and surprise. The oppression comes from one party's overwhelming power over the other that enables him to take advantage of the other party. Surprise exists when the misinformed party supposedly agrees to what are, in actuality, hidden terms designed to defraud him.

\section{Substantive Unconscionability}

Substantive unconscionability is a term used to describe the terms of a contract in that the terms, or "substance" of the contract, are unfair. Substantive unconscionability is found when the terms of a contract are oppressive or cruel to the extreme. Substantive unconscionability is found in cases wherein the terms of the contract themselves would raise a red flag as to the contract being suspect, provided the person reading those terms knew what to look for.

\section{Three Elements Necessary to Prove Unconscionability:}

i. Unequal bargaining power (usually consumer, not commercial)

ii. Dictation of terms of contract by stronger party an Adhesion Contract

(stuck with terms)

iii. Terms manifestly (obviously) unfair or oppressive

\section{Examples:}

i. Williams vs. Walker Thomas: a series of contracts, they say if you default on anything, they can take everything, even if it was already paid off

ii. Campbell's Soup case: gave Campbell's the right to reject the Carrots for any reason, and had a no-sale clause if they were rejected.

1. If delivered, Campbell's can reject even if perfect. If rejected, cannot go sell elsewhere either. Campbell's sued and lost be unconscionable.

\section{Unconscionable Example Involving a Trucking Business}

An example of unconscionable conduct can be found in a case wherein one trucker helped another trucker with a start-up business, then failed to receive the compensation he was initially promised. Randall Lemke owned a trucking business in Wisconsin that ultimately went bankrupt. Thereafter, in the spring of 1992, businessman George Arrowood approached Lemke for help in starting his own trucking business: M\&G Trucking, Inc. Lemke agreed on the condition that he would receive half of the company's profits for three years.

Lemke then contacted several of his former customers and asked them to consider hiring M\&G Trucking. He also contacted several of his former employees and asked if they would consider working for $M \& G$ Trucking. He obtained all of the necessary licenses, permits, and insurance to incorporate $M \& G$ Trucking. He also installed a computer system that came with a database of 300 to 500 potential customers for the company and trained Arrowood on how to use the system. Lemke leased to Arrowood the computers, 
software, phones, and other office furniture from his old business at a cost of $\$ 200$ monthly.

After Lemke had invested about five weeks into this project, he and Arrowood drafted up and entered into a written contract that would "clarify and document" their initial agreement. The contract read, in part:

"[Lemke] shall provide assistance in the form of "startup labor" to M\&G Trucking Ltd., for a period of 5 weeks without pay, commencing on April 9, 1992 and extending through May 15, 1992. [Lemke] shall be paid in the amount of $\$ 8.00$ /hour for each hour of work put in for [M\&G Trucking] following the startup period.

[Lemke] shall be paid an additional amount equal to $1 / 2$ of the net profits arising out of the trucking operation known as M\&G Trucking Ltd...Payment based on net profits shall be paid at least yearly within one month of the end of the year; however, net profits shall never be less than $\$ 400.00$ per month to [Lemke] under this provision for use of the equipment set forth in paragraph 6 .

This agreement shall be effective initially for a period of three years starting from the effective date. This agreement shall automatically renew on identical terms of compensation for a similar period unless specifically revoked by either [Lemke] or [Arrowhead] within 6 months, but not less than 60 days, from the end of the agreement.

[Lemke] shall lease to [Arrowood], as part of this contract, the computer equipment and software, office furnishings, and phone system currently located at 1220 Depot St., Manawa, WI. For income tax purposes, the payment of $1 / 2$ the profits to [Lemke] shall be designated as rental payments for the use of the above mentioned equipment. [Arrowood] is not authorized to copy any of the software or programs, without the consent of [Lemke]. This agreement may be voided at any time by the mutual consent, in writing of both [Arrowood] and [Lemke]."

In the fall of that year, Lemke asked Arrowood to buy the equipment that he had been leasing to $M \& G$ Trucking. Arrowood paid Lemke $\$ 5,200$ to buy everything but the computers, which Lemke then repossessed. Arrowood attempted to clarify with Lemke whether his purchase of the equipment effectively ended their initial contract. Lemke told him that, while the purchase did, in fact, void the rental part of their agreement, he still expected to be paid half the profits for three years as the two had initially agreed.

Ultimately, Arrowood never paid to Lemke any of the profits he earned from M\&G Trucking, nor any other compensation for Lemke's start-up help. Further, neither party had ever terminated the contract in writing. Lemke then sued Arrowood in 1996 for monetary damages in the amount of either $\$ 200$ per month, or half of $M \& G$ Trucking's profits for the six years that followed the signing of the contract.

\section{Decision after Trial and Appeal}

The case went to trial, whereupon Arrowood argued that Lemke had breached the contract in his seizing of office equipment. The trial court dismissed the matter, finding that the contract was unconscionable and that there was no evidence that the court could use to calculate damages. The court also found that the contract did not require Lemke to do anything in particular, so Arrowood's argument was moot.

The matter was appealed to the Court of Appeals for the State of Wisconsin. The Court of Appeals ultimately held that the trial court's decision was to be reversed, and that Lemke was entitled to $\$ 77,462.35$, plus costs, in damages. Because Lemke had not provided enough evidence to the Court that the Court could use to calculate what he was rightly owed, the Court came to this number by adding up everything he was owed by analyzing the profits made by M\&G Trucking over the period in question.

The Court also justified its reasoning insofar as not declaring the contract procedurally or substantively unconscionable. Specifically, the Court wrote:

"The record does not establish the contract was substantively unconscionable. First of all, Lemke performed approximately 200 unpaid hours of work for Arrowood...But Lemke gave Arrowood more than the benefit of his time. He also gave him the benefit of his expertise and his prior business contacts. In addition, the arrangement allowed Arrowood to get up and running without an outlay of capital which he apparently did not have. In exchange, Arrowood promised to pay at least $\$ 400$ a month (including $\$ 200$ per month toward the lease of office equipment), 
or $\$ 14,400$ over a period of three years. This was not so unreasonable as to be viewed as profoundly unjust.

...The fact that Lemke provided only limited services after the execution of the contract does not make the automatic extension provision unconscionable, because either party could cancel the extension within six months but not less than sixty days from the end of the first three-year term, and the parties could mutually agree to terminate the contract at any time. The fact that Arrowood may have failed to exercise his right to cancel the extension after it became clear that Lemke was providing no further benefit to him does not make the contract itself unconscionable. Because we conclude the contract was not substantively unconscionable, we need not consider whether there was any procedural unconscionability in the parties' positions."

\section{Article 2-302. Unconscionable contract or Term. Under UNIFORM COMMERCIAL CODE}

(1) If the court as a matter of law finds the contract or any term of the contract to have been unconscionable at the time it was made the court may refuse to enforce the contract, or it may enforce the remainder of the contract without the unconscionable term, or it may so limit the application of any unconscionable term as to avoid any unconscionable result.

(2) If it is claimed or appears to the court that the contract or any term thereof may be unconscionable the parties shall be afforded a reasonable opportunity to present evidence as to its commercial setting, purpose, and effect to aid the court in making the determination

\section{Related Legal Terms and Issues}

Contract - An agreement between two or more parties in which a promise is made to do or provide something in return for a valuable benefit.

Damages - A monetary award in compensation for a financial loss, loss of or damage to personal or real property, or an injury.

Duress - Threats, intimidation, or bullying intended to force someone to do something.

Fraud - A false representation of fact, whether by words, conduct, or concealment, intended to deceive another. 